\title{
العدل الإلهي في العراق القديم \\ من خلال نصوص مختارة \\ دراسـة تاريخية
}

أ.م.د. غسان عبد صالح- كلية التربية/ ابن رشد

المقلدمة

شغلت نظرية العدل الإلهي بال الأديب العراقي القديم، مما جعلته يثير عبر نصوصـه الأدبية كثير من التساؤلات، حول عدالة الإلهة، التي يعبدها ويقدم لها الهدايا وتسـاؤلاته هذه دفعت بالباحث إلى اختيارها عنوانـا لموضوعه، ألّا أن الدراسـة ستختصر على نصوص معينة، والسبب في ذلك أنها كانت الرائدة في هذا الجانب، وفي اللحظة التي ينتفي فيها العدل الإلهي وتتحول الإلهة إلى كلاب تلهث وراء غرائزها، ذهبنا وراء الأسباب التي قادت إلى فقدان صفة العدل من الإلهة. قسم البحث إلى محاور متعددة سبقتها المقدة، وختمت بأهم ما توصل اليه الباحث من خلال دراسته وبينهما كان هناك ستة محاور في الاول منها وقف التمهيد وكان يعرض النصوص ووقت تأليفها واهم مميزاتها الفنية فيما حمل المحور الثاني من البحث عنوان الخطيئة، ولان الخطايا هي من تسبب نقمة الإلهة فكان لابد من التعريف بها وأنواعها حتى يمكن ان نتعرف على خطايا الثخوص الذين جاؤوا في النصوص التي سيتم عرضها ان وجدت، وعرضت النصوص المختارة بثلاثة محاور كان الاول منها مخصص للصـابر المعذب وفيه تم عرض بعض النصوص التي تشير إلى عذاباته دون ذنب يذكر، واعتقاده بعدم وجود العدل الإلهي، ولا يبتعد عن ذلك كثيراً المحور التالي الذي بحث عن العدل الإلهي من خلال الحوارية بين صديقين ولا يختلف كثيرا في رسمه للإلهة والعدل الإلهي عن سابقه، ولم تتوقف تساؤلات العراقيين عند هذا الحد الذي وجد في النصين السـابقين بل ظل مستمرا وظلت تسـاؤلاته واستخرابه من موقف الهته عبر نص اخر انضوى تحت عنوان حوار بين السيد والعبد، وهذا المحور من البحث لم يختلف عن سابقيه لان النص حمل معالم النصوص السابقة ذاتها. وكان لابد من وققة حول الأسباب التي دفعت بالعراقيين القدماء إلى الاعتقاد بعدم وجود عدل الهي ( هذا الاعتقاد لا يمكن ان نعمده على كل حياة العراقيين القدماء ) أو 
بعبارة أخرى لماذا شكك العراقيون القدماء بعدل الهتم، وهذه الوقفة كانت عبر المحور الأخير من البحث،

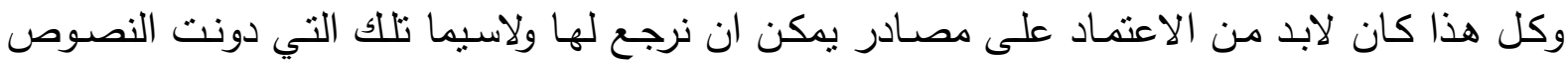

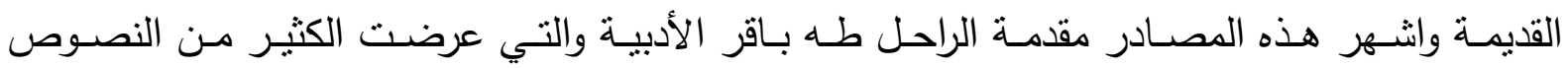

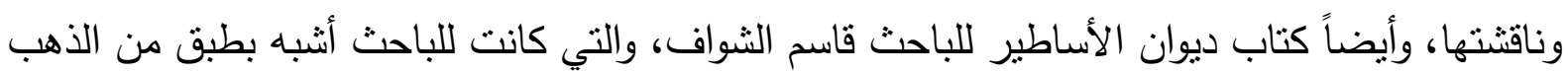
جاء بجميع النصوص، وساهمت كتب أخرى كل في مجاله في إعداد البحث. ومن الله التوفيق

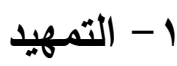

العدل الإلهي (Theodicy) شغل بال أدباء بـلاد الرافدين، كما شغل بال الكثيرين، وجسد هذا الانشغال من خلال نصوص عدة، والبحث هذا سيتتاول ثلاثة نصوص في محتواها ومستواها الأدبيين

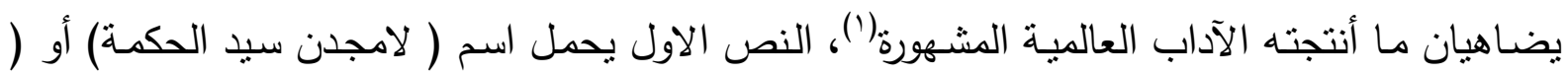

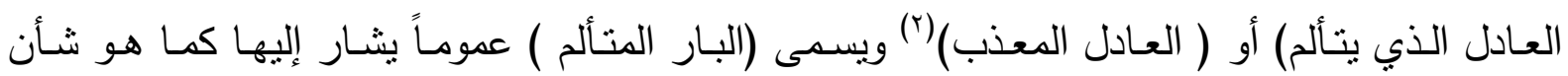

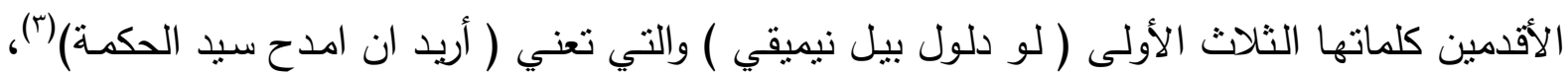

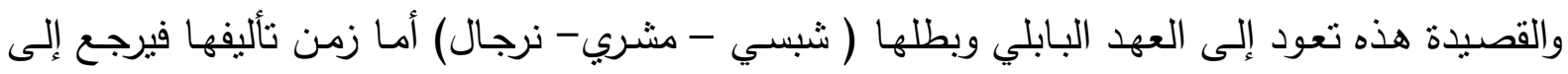

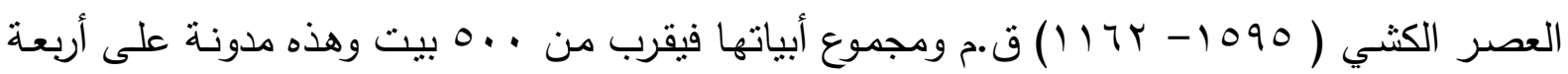
الواح)

النص الثناني والذي حمل معـالم فلسفية شـبه دينيـة، فكان لمؤلفهـ ( سـاجيل - كينا موبيب)

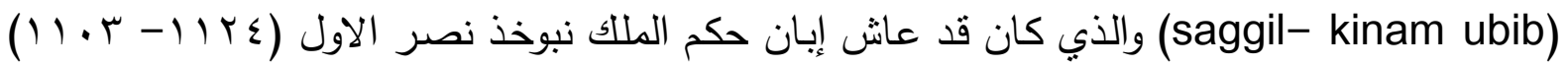

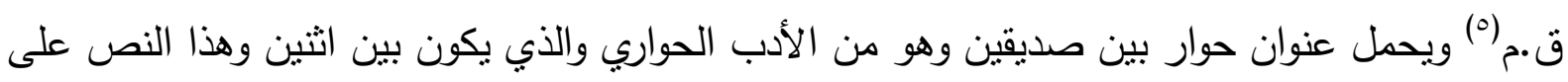
عكس الاول والذي كان عبارة عن مناجاة فردية، ويضم النص سبعاً وعشرين قطعة وتضم كل قطعة احد الإن

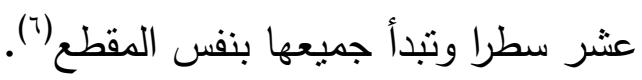

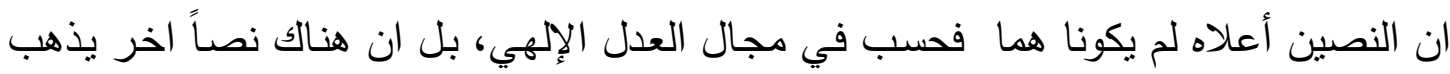

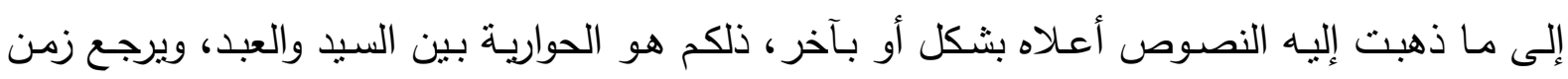


تأليفه إلى مطلع الألف الأول قبل الميلاد، والحوارية هذه كانت تتفرد بأصالتها وجرأتها في التشكيك بالقيم

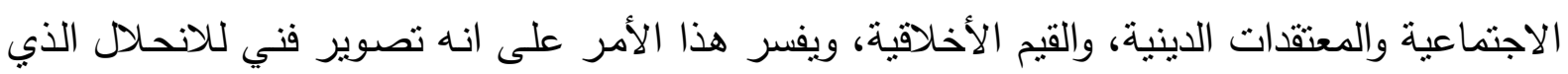

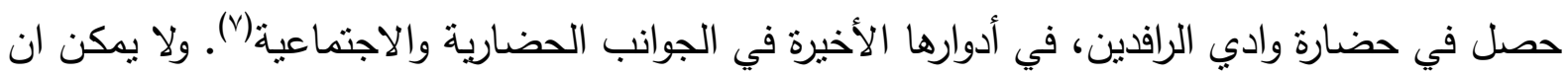

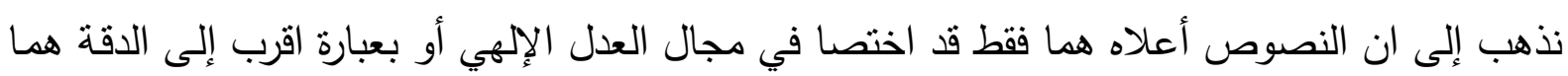

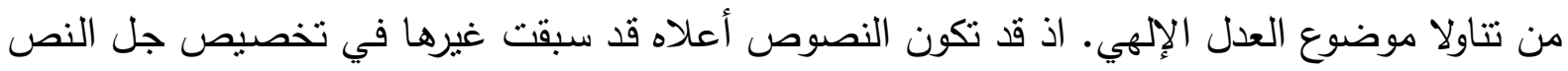
لموضوعة العدل الإلهي.

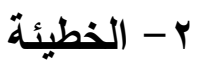

اعتقد العراقيون القدماء ان استمرار الكون والعيش بسلام وهدوء، كان يكمن في إرضاء الإلهة، واذا ما غضبت الأخيرة فان الانتقام سيحل على البشر نظير تقصيرهم في إداء ما القي على عاتقهم من

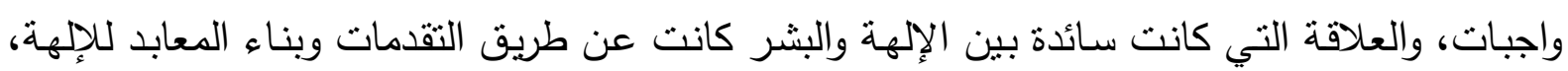

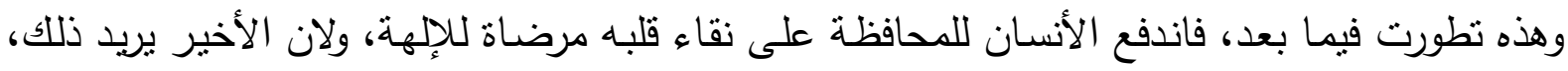

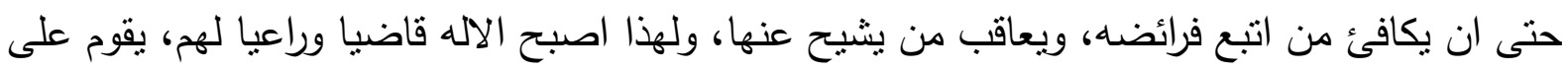
إقامة العدل الإلهي فيما بينهم، أما الناس فقد استقر في نفوسهم الرهبة من عقاب وانتقام الإلهة: (^).

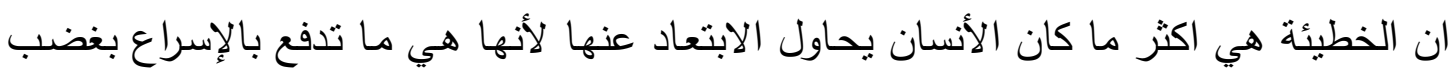
الإلهة، وهذه أي الخطيئة وردت في النصوص المسمارية بصيغة (Nig - gig) وهي تثنير إلى الخطيئة

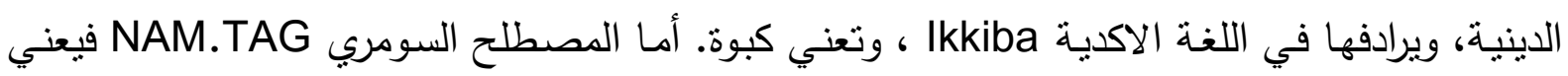
الخطيئة في غير الجوانب الدينية، وهي معصية مرتكبة ضد القوانين المدنية ويرادفها في اللغة الاكدية

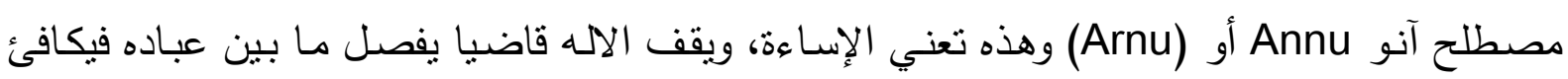

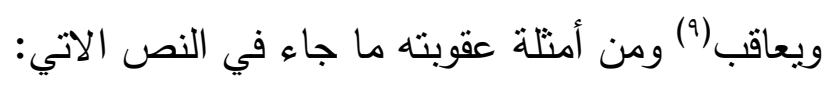

$$
\text { الهتي الهملني وغاب إلى الأبد }
$$

وعني افترق الملهم الخير الذي كان برافقني عئي 


$$
\text { ذهبت صرب ملاكي الحارس مفتشا عن غيري الجيدة، ودفعة واحدة }
$$

واذا ما استمرت الخطيئة سلط عليه عذاب اكبر ومن عذابها الوباء وكما في النص أدناه:

عندما سمع انليل ضجيجهم

توجه إلى الإلهة العظام قائلاً

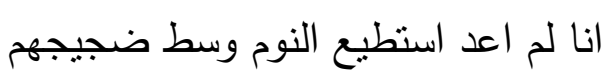

اصدروا أذن أوامركم لكي يصبهم الوباء(')

هذا وان كل ما سيلحق بالإنسان من ضيق أو تدهور في حياته كان يفسر كنتيجة لغضب الهي، وهذا مـا يدفع بالإنسـان إلى تسكين الإلهة عن طريق التضرع وتقديم القرابين، وعندما يستمر الغضب الإلهي ولن تفلح تهدئة الأنسان لله فان الأخير يعد نفسه مسؤولا عنها لجهله أو إخفاقه في كسب رضا لإنسا

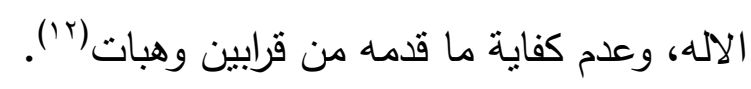
ولهذا نجد الأنسان دائم التوسـل بالإلهـة محاولا التقرب لها وهذا نص ابتهال موجـه إلى الالهـ . نرجال * حاول المتقرب منع غضب هذا الاله، وكما يأتي:

انا فلان ابن فلان خادمك بما ان غضب الاله والإلهة تسلط عليّ فالضياع والخراب دخلا بيتي وصلاتي دونما استجابة، حرمتني من النوم وبما انلك يا الهي فائق الحلم نحو الوهينك استدرت ولأنك تعرف كيف تغفر فنتت عنلك ولأنك تتظر بعين العطف، تأملت وجهك 


\section{ولأنك رحيم، انا هنا واقف أماملك \\ انظر الي برفق، استمع لصلاتي \\ وليهدأ قلبك من اجلي، اذا ما كان غاضبا \\ حل خطاياي وأخطائي، بدد تقصيري \\ وليهدأ دونما تأخير غضب الوهيتك ضدي \\ وليعاملني بمحبة الاله والإلهة المتفعلين \\ وانا سوف ابلغ عن عظمنك وانشد نسابيحك(r) \\ والخطيئة يمكن تصنيفها إلى أنواع عدة وعلى النحو الاتي: الإلههة(10).}

أولا - خطيئة تتسـب إلى البشـر قسرا، وهذا يمكن تفسيره إلى ان الإلهـة وحسب التصـور ، سكان بـلاد

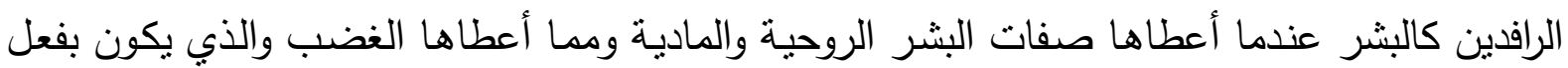
عوامل مختلفة(أ). ولهذا فان غضبها، ينعكس على البشر بشكل خطايا وذنوب ولهذا فان الأنسان يعد غير مسؤول عن الخطايا والذنوب التي يرتكبها، لان ما ارتكب كان بفعل الإرادة الإلهية وان مسؤوليتها أي الخطايا تقع على عاتق الإلهة، ولهذا فان الآلهة سبيت مثل هذه الخطايا سوف تحاسب أمام مجلس

ثانيـاً- خطيئة تنسـب للإنسـان نفسـه، ولعل ذلك كـان منطلقا مـن طبيعـة سـوكية الأنسـان ورغبته في التصرف تجاه ما يربد ان يفعله وبين ما يجب ان يمتتع عنه ويلاحظ ذلك من خلال النص الاتي والذي هو عبارة عن نصائح من حِكيم إلى تلميذه وعلى النحو الاتي: لا تتتهر قليل العقل، بل اثفق عليه

لا تزدر الذين هم عرضة لتجربة

لا تثوجه اليهح بغطرسة

لأنه من اجل ذلك يهجرك الهك الثخصي الذي يحميك 
وهذا أيضاً مكروه لدى شمش ويعاقب عليه(T').

ومن نص اخر يمكن التعرف اكثر عن هذا النوع من الخطيئة :

الذين اذ يسلكون طريق الخطيئة يتجاوزون اليد العليا

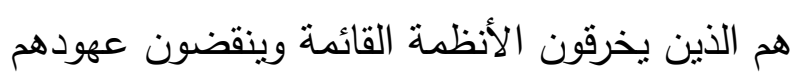

الذين ينظرون بعين الرضا إلى أماكن السوء

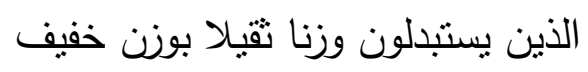

الذين يستبدلون قياسا كبيرا بقياس اصغر

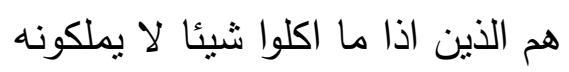

لا يقولون انا أكلته

واذا ما شربوه لا يقولون انا شربته

هم الذين يعلنون سوف اكل كل ما هو محرم

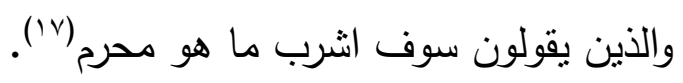

ثالثاًا - خطيئة بسبب الطبيعة التركيبية لبنوية الأنسان، فالاعتقاد الذي كان سائدا لدى سكان بلاد الرافدين ان الأنسان خلق من دون الاله الخاطيء المذبوح، وكما يتبين من خلال النص الاتي:

$$
\text { كينغو * وحده }
$$

هو الذي حرض على القتال

$$
\text { ودفع تيامت * إلى الثورة }
$$

عند ذلك عمد على تقييده

$$
\text { وأتي به امام ايا }
$$

ومن ثم ولكي بتلقى عقابه

تمت اسالة دمه ومن 


\section{وبدمه انتج ايا البشر (1)}

وهذا النص يؤكد على ان الأنسان مجبول بدم اله خاطئ وهو أيضاً يربط الأنسان والإله بصلة

ومما سبق فان الخطايا والذنوب والآثام التي يرتكبها أنسان بـلاد الرافدين كانت عمداً أو سـهواً

سواء أكانت ضد الإلهة أم ضد الأنسان، هذا مع الأخذ بنظر الاعتبار ان الخطيئة قد تكون جماعية، أي

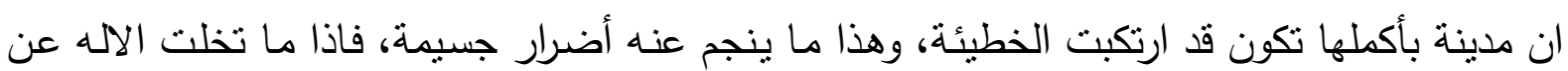

المدينة المذنبة يعني تعرضها للكوارث والويلات والاضطرابات وتسليط الأعداء عليها(·r).

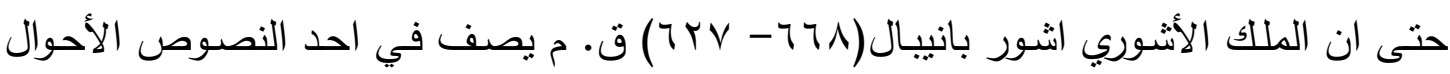
التي وصلت اليها بلاده وحسب اعتقاده فانه كان عقاب قد تقرر ضد بلاده كما يبين النص الاتي:

$$
\text { ( لماذا يحيط بي الألم ومرض القلب والثقاء والألم }
$$

وفي البلاد تتنشر الاضطرابات، وفي البيت تحاك الدسائس

$$
\text { والكوارث والكلمات الثديدة تلازمني }
$$

في اليوم المخصص لاله المدينة، يوم الوليمة

اصبح الموت نهايتي، اني أتعذب بالقلق والحزن

أيها الاله .. سلط هذا على الذين، لا يخافون من الإلهة

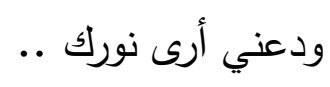

$$
\begin{aligned}
& \text { أيها الاله لم قررت كل هذا عليّ } \\
& \text { إنني أتعذب منل الذي لا يخاف الإلهة (r)" } \\
& \text { r- العدل الإلهي من خلال نص العادل المعذب }
\end{aligned}
$$

مثلمـا ذكر سـابقا ان الخطيئة التي يأتي بها البشر تستوجب ودون شكك العقاب لكن مـا يلفت الانتباه ان الصابر المعذب لم يأتِ بأي خطيئة بـل انه يذكر مزاياه واذا بها مزايا أنسان قد آمن بالإلهة وصرف جل وقته لخدمتها والتثقيف لها، وهذا ما يبدو من خلال النص الاتي: 
اذا نظرت ورائي فليس سوى اضطهاد واضطراب منل من لم يضمن السكائب للإللهة أو لا يكون قد دعا الهته إلى طعام

أو لا يكون قد احنى وجهه أو سجد بصورة علنية مثل من في فمه قد تكون قد بطلت الصلوات والطلبات وقد يكون قد اهمل يوم الاله وتغاضى عن الأعياد الثهرية أو يكون قد نسي واهمل عبادة الإلهة ولا يكون قد علم اتباعه لا الخوف ولا الاحترام والذي، دون استدعاء الهه يكون قد تتاول الطعام أو اهمل الهته دون ان يجلب لها تقدمه الدقيق(r؟). ويستمر الصـابر المعذب في تعداد مـا جبلت عليه نفسـه تجاه الهته، والتي جلها تؤيد انه كان متضرعاً خائفا مؤمنا بها وكما في النص: كان الطلب حكمة لي، والقربان شريعتي اليوم الذي فيه يكرمون الاله كان بهجتي وبوم التطواف بالإلهة كان لي ربحا وفائدة(rr).

والى غيرها من مفردات النص والتي كلها تعلن ودون شك إلى ان العادل المعذب لم يقترف أي خطأ من شأنه ان يعاقب عليه، حتى ان كريمر في ذلك يقول ان العادل المعذب كان غنيا وحكيما وعادلا وكان ينعم ببركة صفاء العيش مع الأصدقاء وذوبي القربى، لكنه أصيب في احد الأيام وبـلا سبب واضـح بالسقم والعذاب وخيانة الأصدقاء وكره الناس لله (؟؟). وما يشار اليه انه على الرغم من التقى الذي كان عليه المعذب الا انه جوبه بعقوبة كبيرة فجزء منها كان على صعيد الصحة، اذ فقد المعذب الصحة التي كان يتمتع بها وعلى النحو الاتي: وجاء فوق ذلك مرض مضن 


$$
\begin{aligned}
& \text { وهبت علي ربح ردئية } \\
& \text { لقد انتشرت حمى - ايغو *- من سطح العالم السفلي } \\
& \text { وخرج السعال الردئ من ابسو فجأة } \\
& \text { ومع النهر الفائض جاءت الرجفة الباردة } \\
& \text { ضربت رأسي والّمت بجمجمتي } \\
& \text { فأظلم وجهي وزاغت عيناي } \\
& \text { واجتازت هذه الآلام على رقبتي وشلت عنقي } \\
& \text { أصابت صدري وضربت أحشائي (ror). }
\end{aligned}
$$

ويستمر النص على هذا المنحى وفي نهايتهـه تكون كل أجزاء الجسـم قد تعرضـت للمـرض عـ المهلك(זr). أيضاً مما أصاب المعذب فقدانه لمركزه ومكانته سواء على الصعيد الوظيفي أو على الصعيد الاجتماعي، وهذا ما بظهره النص أدناه:

انا المتبختز منل سيد تعلمت ان أسير في الظله

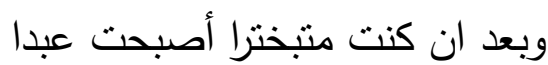

وعوض أسرتي الواسعة أصبحت وحيدا

حينما امشي في الثارع، تشير الأصابع الي

واذا دخلت البلاط، تغامزوا علي

مدينتي تتظر الي بقساوة منل عدو

لقد انقلب أخي إلى غريب

ورفيقي إلى شرير وشيطان

وزميلي يصقل أسلحته ضدي

علنا في المحكمة لعنني عبدي(rV). 


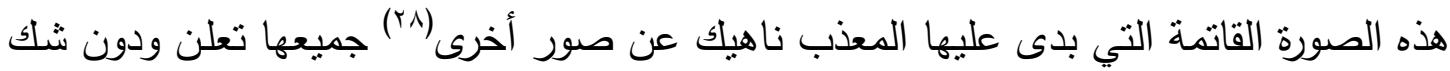

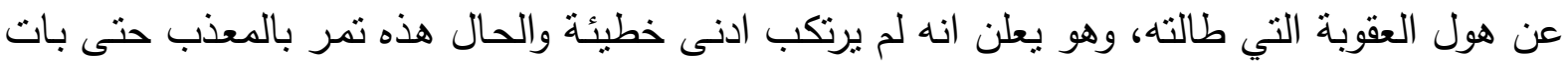
يائسا من رحمة الاله وهذا ما يؤكده بقوله: علاماتي أفزعت المعزم

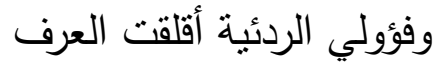
ان المتعوذ لم يحلّ طبيعة دائي ولا العراف حدد نهاية لألمي لم يأت الاله إلى عوني ولم يأخذ بيدي الهتي لم تشفق علي ولم تنر بقربي(19).

ما حدث بعد هذا اليأس كان كأنه بداية الانفراج للازمة التي مر بها اذ رأى أحلام ثلاثة ظهر لـه

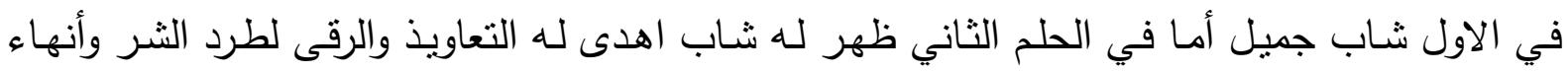

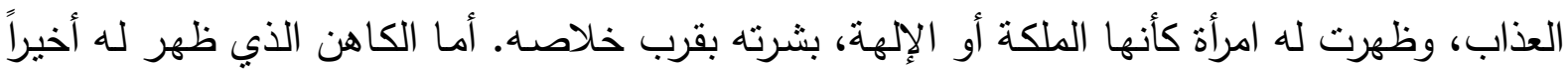

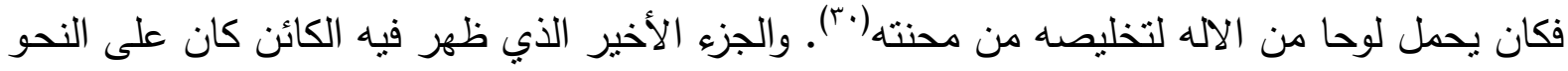
الاتي: - n

$$
\begin{aligned}
& \text { هكذا سلمني مردوخ إلى يدي شافي } \\
& \text { في حالة اليقظة ارسل الي رسالة }
\end{aligned}
$$

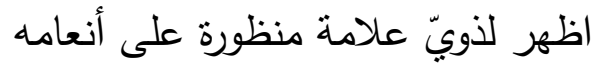

$$
\begin{aligned}
& \text { من الألم الذي كان يطول ( اخرجني بسرعة) }
\end{aligned}
$$

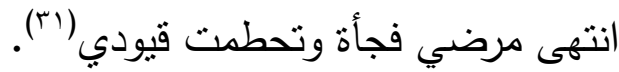

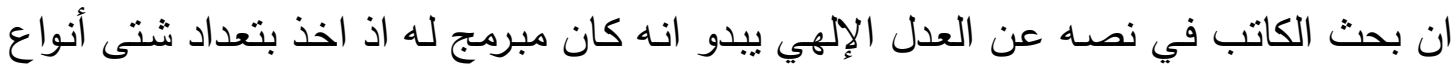

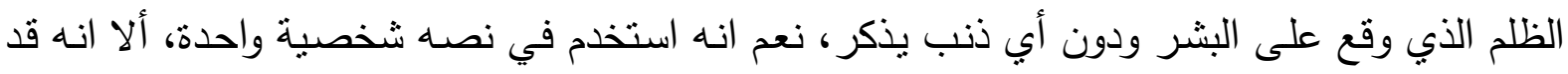


يكون في اختياره هذه الثخصية المجتمع، أو مجموعة كبيرة من الناس، وبدء بالبحث لها عن من يوفر

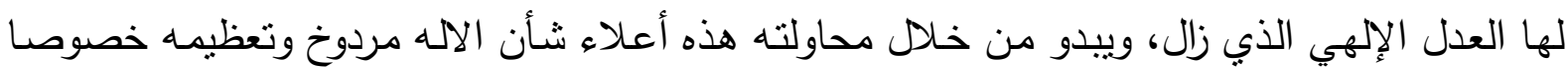

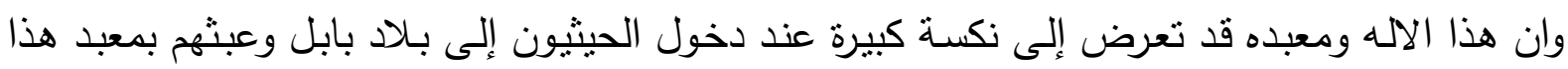

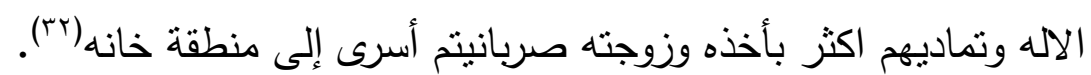

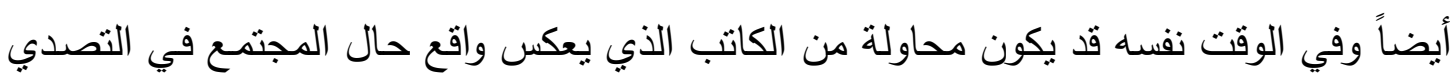

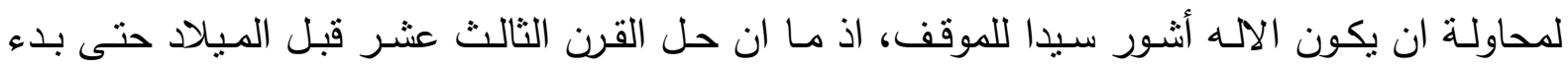

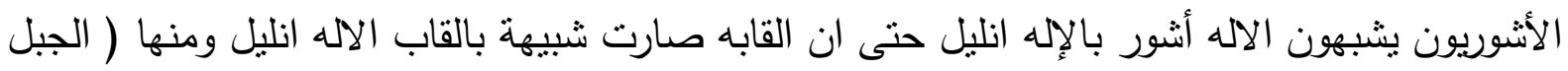

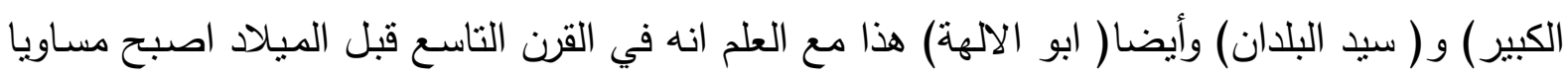

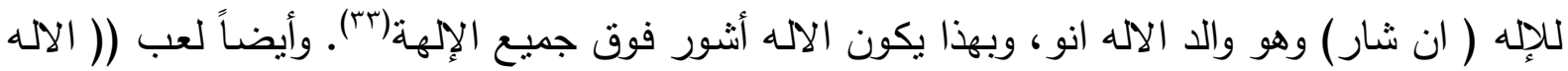

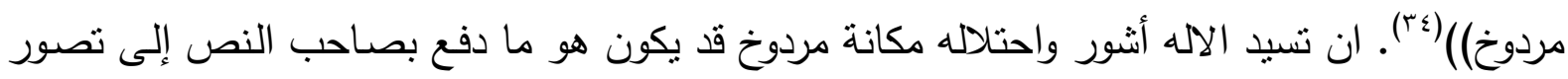

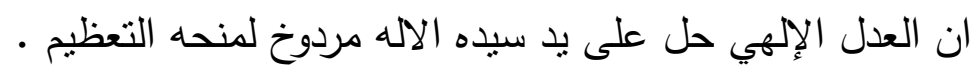

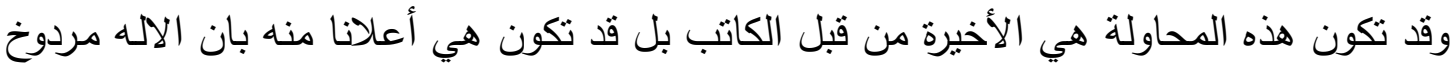

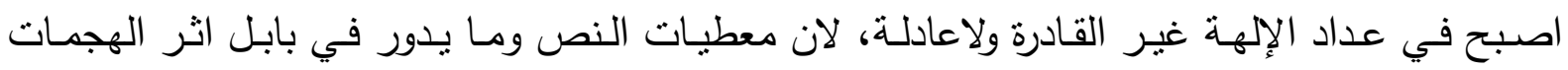

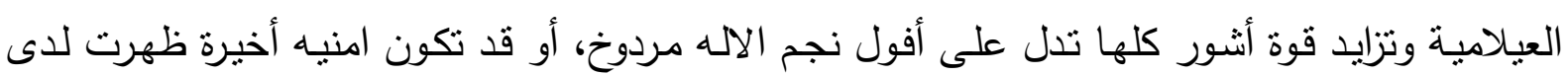

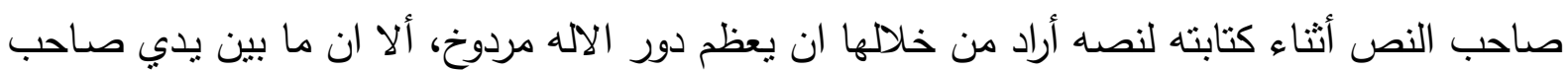
النص يشير ودون شك إلى تدهور مكانة مردوخ.

\section{ع - العدل الإلهي من خلال حوارية بين صديقين}

النص الذي يوصف بانه نص قائم على التتكيك والسخرية من جانب المعذب، والذي وصل

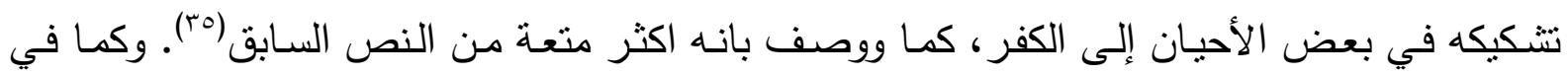

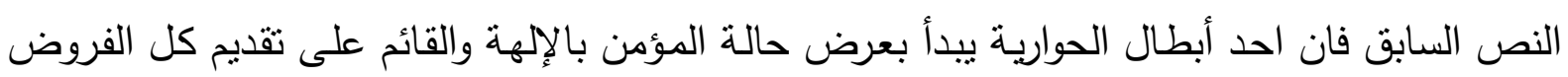

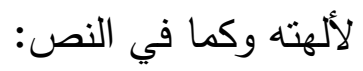




$$
\begin{aligned}
& \text { أتقاعست انا، عن تقديم القرابين ؟ } \\
& \text { لقد صليت إلى الاله } \\
& \text { وبكل تقوى قدمت إلى الإلهة قرابين بانتظام } \\
& \text { وكلماتي كانت صادقة } \\
& \text { منذ أيام شبابي نوجهت بنفسي }
\end{aligned}
$$

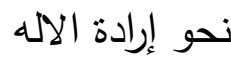

$$
\begin{aligned}
& \text { بالتعبد والصلاة بحرارة وورع وفتشت عن الإلهة } \\
& \text { ومنل نير حملت عبوديتي (بَ). }
\end{aligned}
$$

اذا والحال هذه فأن المتوقع ان الككافئ من قبل الإلهة ستكون منحه أموالاً ومنزليةً كبيرة، ألا ان

$$
\begin{aligned}
& \text { ما حدث في النص الاول يتكرر في هذا النص أيضاً وعلى النحو الاتي: }
\end{aligned}
$$

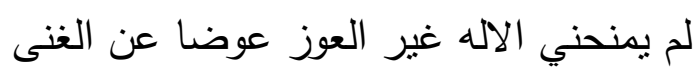

$$
\begin{aligned}
& \text { فالأكسح يفوقني والمجنون بسير أمامي } \\
& \text { النذل يبلغ القمة وانا ينتقص من قدري (rv). }
\end{aligned}
$$

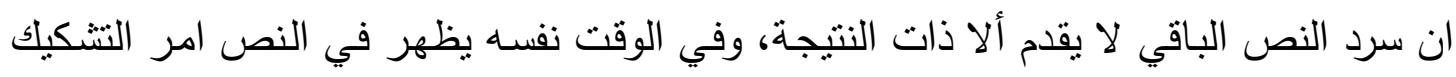

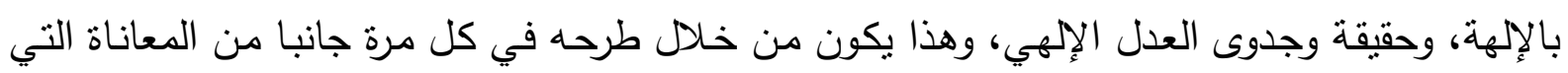

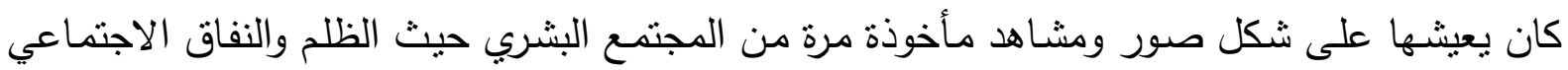

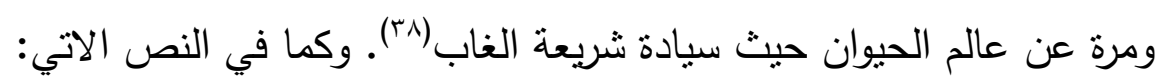

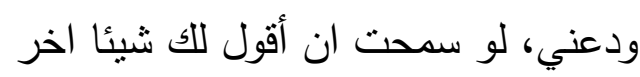

$$
\begin{aligned}
& \text { الحمار الأخدري ، هذا الحمار الوحشي الذي لوني } \\
& \text { يتخم نفسه من انتتاج حصادنا } \\
& \text { هل يعير اذناً صاغية للكاهن الذي لفي } \\
& \text { يؤكد تحقيق إرادة الإلهة }
\end{aligned}
$$




$$
\begin{aligned}
& \text { والأسد المفترس الذي لا يأكل ألا أجود اللحم } \\
& \text { هل يقوم بنقديم قربان طحين } \\
& \text { لتهيئة غضب الإلهة }
\end{aligned}
$$

والحديث الثزاء الذي تضاعفت حقا ممتلكاته

هل يزن من اجل مامي الذهب الثمين

اتقاعست انا، عن تقديم القرابين

لقد صليت إلى الاله

وبكل تقوى قدمت إلى الإلهة قرابيني بانتظام

$$
\text { وكلماتى كانت صادقة (ra). }
$$

المنحى الذي اتخذه هذا الرجل المعذب كان يقابله من جهة أخرى محاوره الذي يوصف بانه اكته اكثر

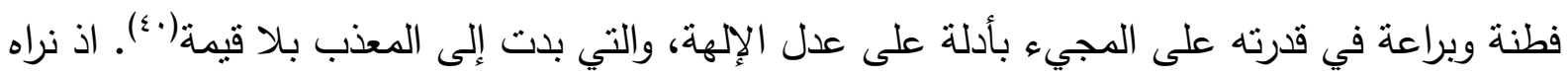

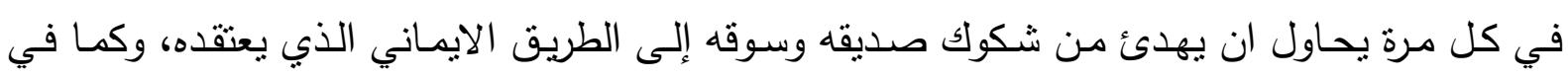
النص:

$$
\text { أيتها النخلة يا شجرة الثراء، أي أخي الغالي }
$$

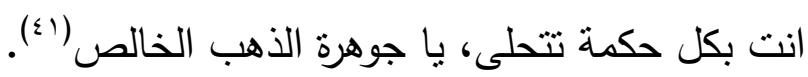

ويلاحظ من النص أعلاه انه يحاول إضفاء الكثير من الصفات ولعلها طريقة لترطيب أجواء

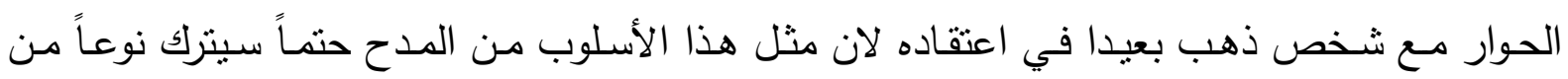
الارتياح لاى الطرف الذي يحاوره، يستمر النص وعلى الندي النحو الاتي:

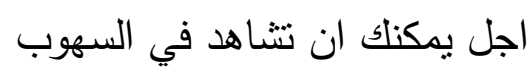
الحمار الوحشي الرائع الجمال

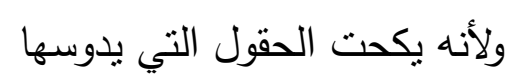




$$
\text { يتوجه السهم نحوه }
$$

هل تريد ان تتأمل عدد الماشية، هذا الأسد

$$
\text { الذي ذهب تفكيرك اليه }
$$

من اجل الأضرار التي يرتكبها فان الحفرة

$$
\text { قد أعدت له اجله }
$$

أما الحديث عن الثراء - الذي تتراكم أرزاقه

$$
\text { فألى النار وقبل دنو ساعته، فان }
$$$$
\text { الملك غالبا ما يحيله إلى اللهب }
$$

هل ترغب باتباع الطريق الذي اتخذه هؤلاء

$$
\text { احرى بك ان تسعى إلى محاسن نعمة }
$$

$$
\text { الاله الدائمة (ك). }
$$

وقد يظن ان المعذب سيقف عند هذا الحد في شكوكه ألا انه يعود فيقدم كلامه بأسلوب لا يقل

$$
\text { عن أسلوب المؤمن دماثثةً وإبداعاً بقوله: }
$$

$$
\text { عقلك هو نسيم الثمال ونفسه محبب إلى البشر }
$$

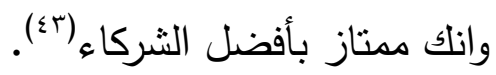

وبعدها يبدأ المعذب وكأنه يحاول أثبات ما اعتقده إلى صاحبه المؤمن اذ يقول له:

$$
\begin{aligned}
& \text { ألا ان كلمة واحدة فقط أربد أضافتها أمامك } \\
& \text { انه لطريق سعادة هو الذي يتبعه } \\
& \text { من لا يبحثون عن الاله }
\end{aligned}
$$

بينما يتحول إلى الفقير المتدينون المتحمسون للإلهة

$$
\text { ويفقدون ممتلكاتهم (ع ؟). }
$$


محاولة المعذب هذه باستعادة مشهر اجتماعي واضح للعيان ومستقى من تجربته ومشاهداته، ما هي ألا لدحض أقوال المؤمن الذي ما انفك ألا وداهمه بان ما محاولته الثكيكية هذه ألا محاولة للهروب من الطقوس والممارسات التعبدية وعلى النحو الاتي: لقد تخليت عن الحق وهزأت بنوايا الاله

ورغبت في داخلك ان نتوقف عن ممارسة الطقوس الإلهية

وفي داخلك نسيت الأنظمة الحقبقية

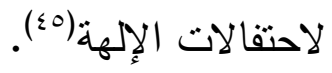

كما وحاول ان يفهم صديقه ان ما حل به لا بمكن ادراك كنهه والحكمة منه لان هذا لا يظهر الا بعد امد بعيد وعلمه متروك للإلهة وعلى النحو الاتي:

مقاصد الآله هي بعيدة عنا كما هي بعيدة أعماق السموات

لا يسعنا ان نسمع ما يخرج من فم الإلهة

ويبقى البشر عاجزين عن فهمها تماما أفكار الإلهة تبقى متعذرة عن البشر ومن المحال عن البشر التعريف بطرق الإلهة:(ب؛).

هذا الأمر وهذه النصائح والتوضيحات لم تجد أي نفع للمعذب حتى انه بعد هذا الحوار نراه اثد عزماً على مغادرة الطريق التي كان عليها من الاعتقاد بالإلهة وبقدرتها فنراه يقول:

$$
\text { أريد هجر بيتي }
$$

طقوسها بقدمي (sv). ( 
ويصف طـه باقر هذا الموقف بانـه استمرار وتمـادي في الثكوك ووصل إلى درجة الكفر (^ء) الحواريـة تستمر لتضـع نظريـة العقاب المقدس على الممارسـات المنتـعبة للحيـاة العقليـة ويكون الاتفاق أخيراً بين المتحاورين على الاقتتاع بان البشر غير عادلين، وانهم كذلك لان الإلهة خلقتهم كذلك(9ء). ولنقف عند النهايـة التي وضـعها سـاكز ولنعد للنص الذي لا ينبئ عن هذا الأمـر بـل ينبئ ان هنالك محاولة ثانية للعودة إلى حياة الأيمان توصل لها المتحاوران، ولعل في ذلك يمكن ان تقول عنه ان منح فرصة ثانية للإلهة لعلها ان تبدي موقفا مختلفاً عن موقفها السابق وكما يبين النص الذي يرد فيه المعذب على المؤمن بقوله:

انت شفوق يا صديقي! فأعتبر أذن قلقي

تعال لمساعدتي انظر إلى ألمي واعلم بانني كنت ساهراً ومحترماً وراجيا ولم اجد قط ولو للحظة واحدة العون أو المساعدة مشيت دون ضجيج في ساحات مدينتي وصوتتي كان دون دوي وكلمتي منخفضة لم اكن متبجحا وكنت مثل عبد بين جميع زمالئي ألا فليمنحي الإلهة الذين اهملوني من جديد عونهم والإلهة التي هجرنتي لتعد من جديد إلى معاملتي بشفقة(-0).

\section{ه- العدل الإلهي من خلال حوارية بين السيا والعبد}

على الرغم من عدم ذكره للخطيئة إلى انه يمكن تلمسها من خلال بعض المفردات في النص، ومع هذا فقد تعرض النص إلى العدل الإلهي، والمنتبع للنص يجد انه يختلف في طريقة عرضـه للعدل 
الإلهي اذ تظهر في النصين اللذين تم تتاولهما من قبل عقوبة من الإلهة على البشر في حين لا يظهر

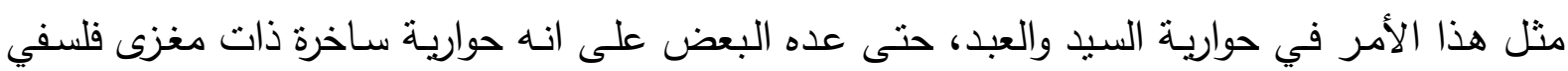

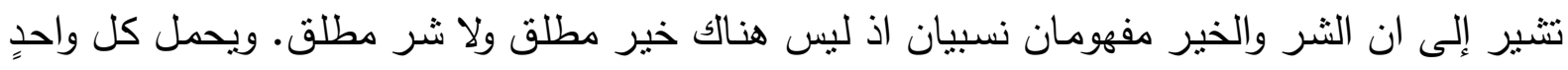
منهما في باطنه بذور على عكس ما يبدو عليه (10). ومنلما ذكر في الصفحات السابقة فان هذه الحوارية ما هي الا تنكيلك بالقيم والمعتقدات الدينية، وهذا ما نلاحظه من خلال النصوص الآتية: أيها العبد تعال هنا وامتتل لأوامري

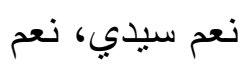

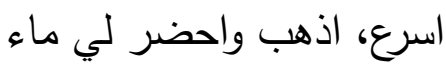
لغسل بدي أريد تقديم قربان لإلهي قام يا سيدي قدم الرجل الذي يقدم قربانا لإلهة برتاح قلبه وبضمن لنفسه اجرا فوق اجر أذن، كلا يا عبد، انا لم أقدم قربانا لإلههي

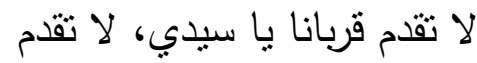
لأنك بذلك سوف تعود الهالك

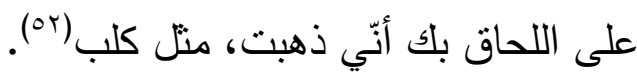
ومن خلال مقطع اخر يمكن ان نستشف الاستهزاء بالقيم الدينية اذ يبدي السيد رغبته في القيام

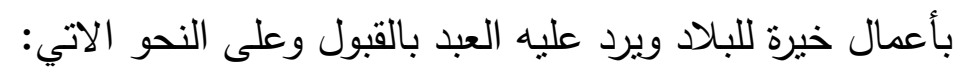
أريد تتفيذ عمل مفيد لبلدي افعل ذلك سيدي الرجل الذي ينجز عملا مفيداً لبلده 


\section{تسجل أعماله الحسنة في سجل مردوك أذن كلا يا عبد، انا لن انجز عملا مفيداً لبلدي في فردي لا تتجز ما يفيد بلدك سيدي \\ اصعد إلى تال انقاض الماضي المتراكمة وتجول فيها تأمل فيها الجماجم المختلطة للفقراء والأعيان

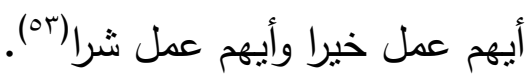
ان النصين أعلاه يظهران ودون شك عدم احترام القيم الدينية، اذ يذهب النص الاول إلى اعتبار

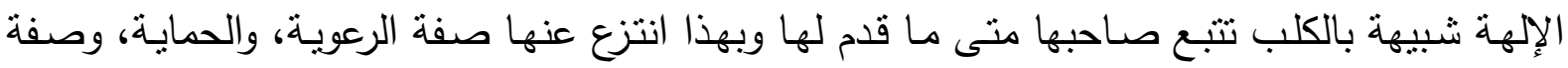
العطف، وحولها إلى حيوان يركض وراء غرائزه، في حين نوقف في النص الثاني عن نقديم عمل الخير.

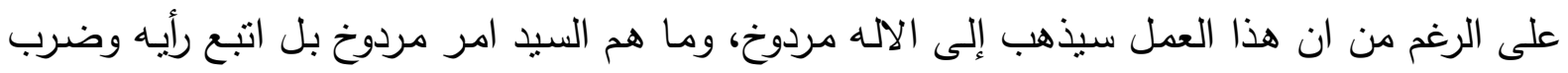

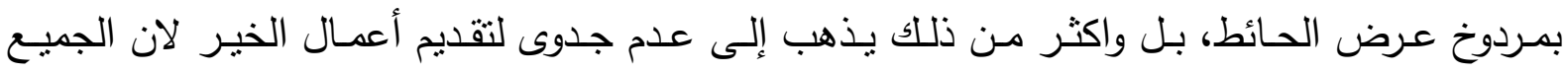

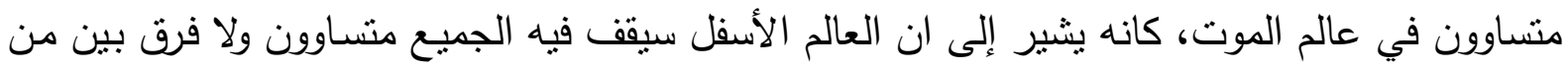
قدم الخير وأخر جاء بالثر ، ان الثكوك أعلاه تثبر إلى أن من جاء بالخطيئة ومن لم يأت بها منساوون

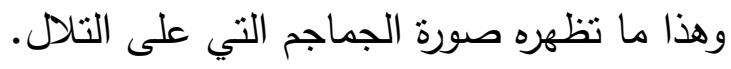

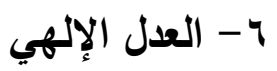

والنصوص السابقة تعلن ودون ادنى ريب ان العدل الإلهي غير موجود اذ كيف يمكن للإلهة ان

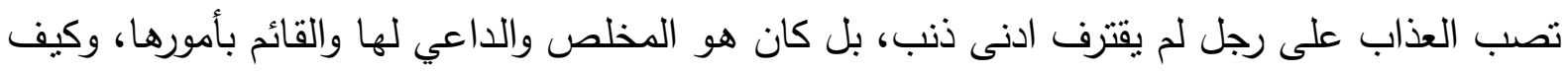

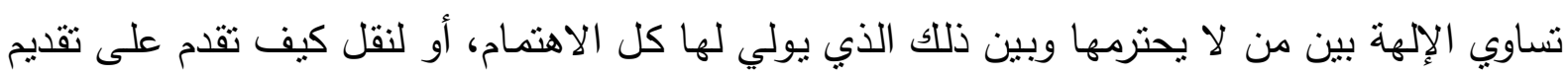
ذللك المنتهك لأمرها وجعله ذات وجاهة، وتنزل النقمات على لإنى خدمتها.

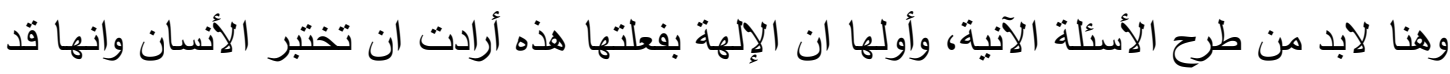

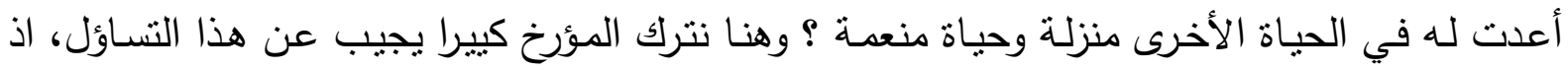

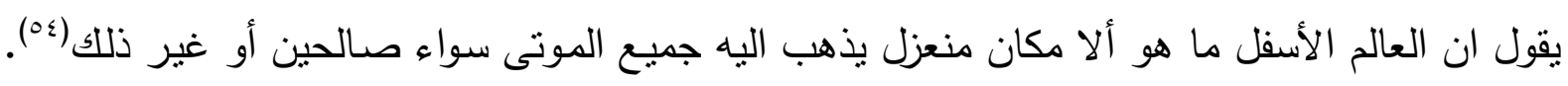


وان عالم الأحياء هو دار الثواب والعقاب وليس عالم الأموات(00، حتى أنها تسمى عالم اللاعودة حسب

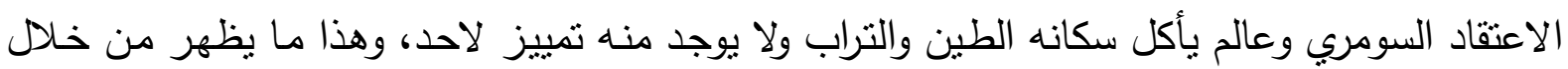
نصوص ملحمة كلكامش وعلى النحو الاتي:

$$
\begin{aligned}
& \text { إلى البيت الذي لا يرجع منه من دخله }
\end{aligned}
$$

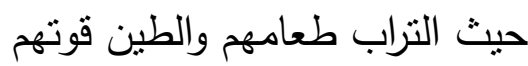

$$
\begin{aligned}
& \text { وهم مكسوون كالطير بأجنحة من ريش }
\end{aligned}
$$

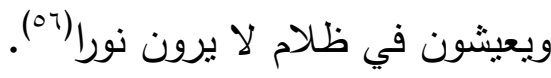

أيضاً ومن خلال نص اخر نستدل على ان العالم الأسفل لا تمييز فيه حتى ان انكيدو يصفه

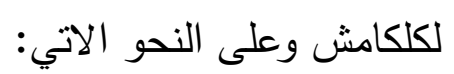

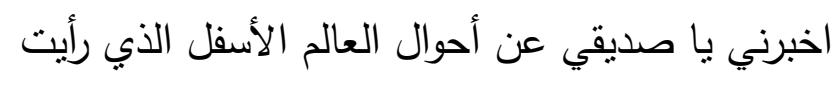

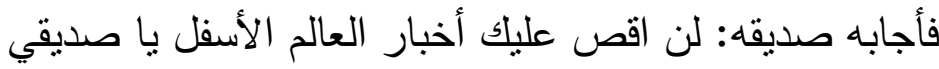

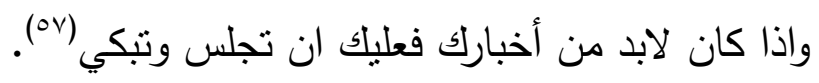

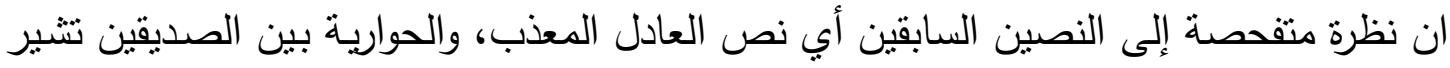
ودون شك إلى ان البطلين تمت معاقبتهما دون ادنى ذنب وهذه قاعدة ما يجب ان يكون عليه الاله من

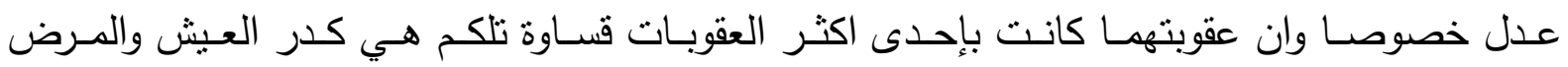

التساؤل الأخر قد يكون الثخصان اقترفا ذنبا استحقا عليه العقوبة التي وردت في النص ؟ وان

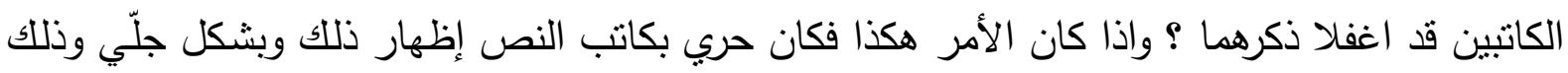

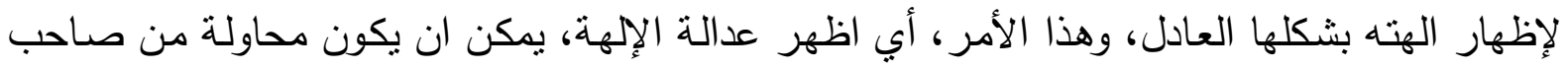

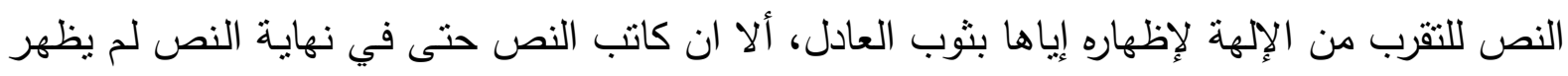


أي دور أو قوة للإلهة في رفع المظالم التي لحقت بالمعذب، ويبدو انه تعدد في ذلك كثيراً لأثبات شكوكه

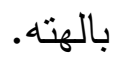

منلمـا هو معروف فان الأدب هو مرآة حقيقة عاكسـة عن كل مـا يدور من أحداث سياسية

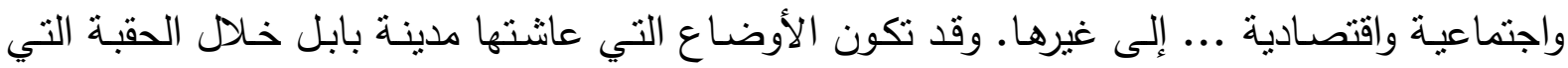
كتبت فيها النصوص قد القت بظلالها على صاحب النص ودفعته هذه الأحداث إلى النتكيلك بعدالة الإلهة، خصوصا وان احد النصوص كتب في عهد الدولة الكثية (1090- بآ 11) ق.م ومعروف ان

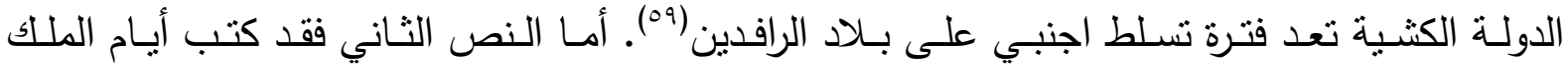

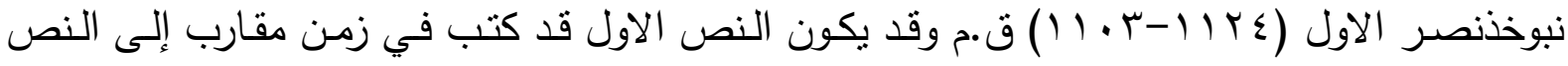
الثاني لذا حملا إلى حد كبير الثكوك نفسها تجاه الإلهة، والفترة هذه شهدت فيها بلاد الرافدين الكثير من الأن

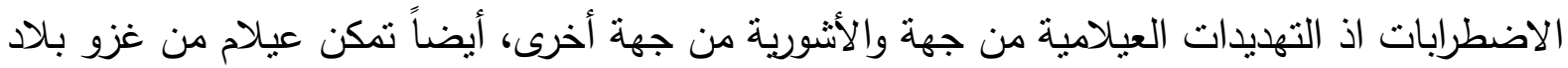

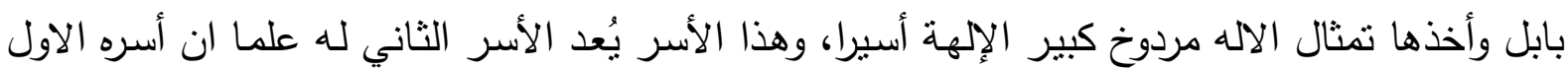

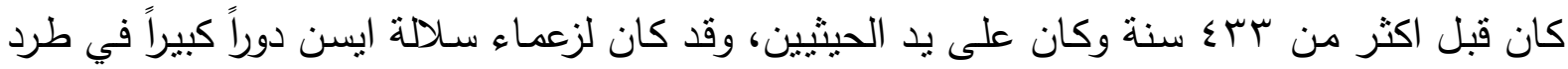

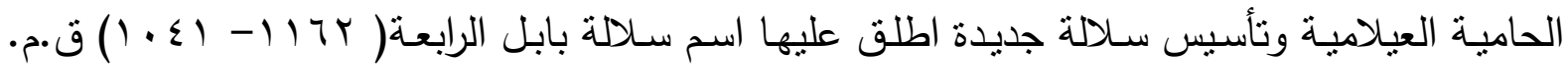

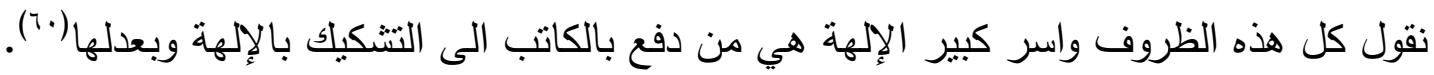

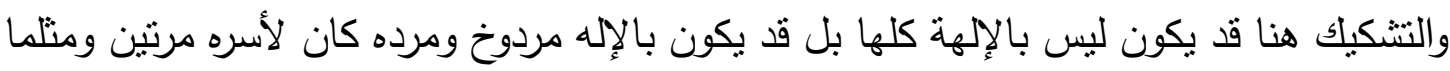

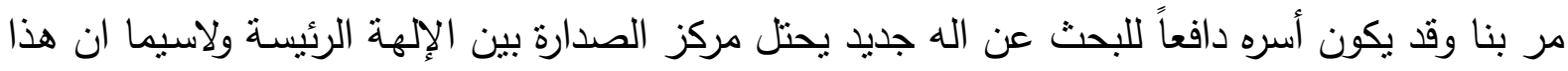

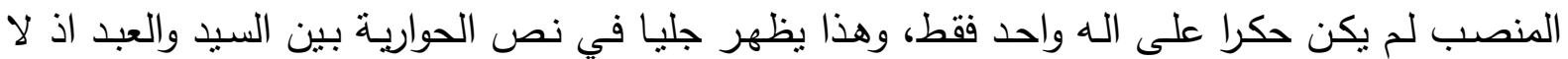

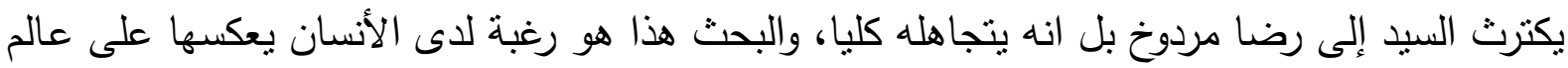
الإلهة في تغيير اله محل اله اخر وهذا ما نلاحظه من خلال النص الاتي:

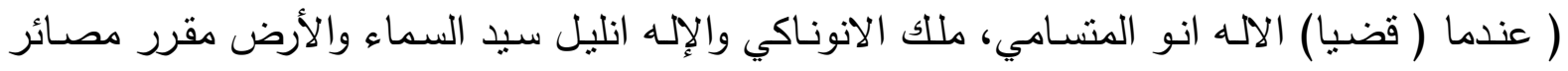

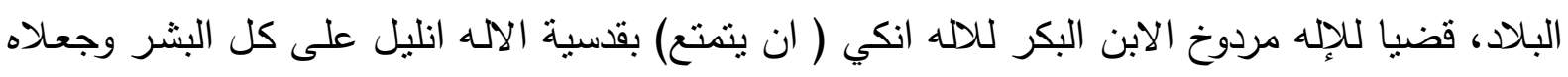

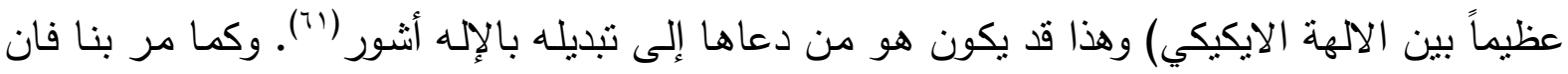

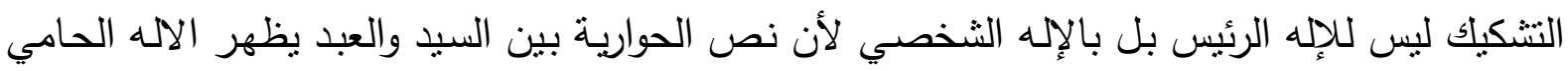


مثل الكلب وهذا اقسى مـا ذهب اليهـ النص، علمـا ان نص الحواريـة لم يختلف عن سـابقيه في زمن التدوين، كما وأن الاله الحامي له دور مهم جدا بالنسبة إلى سكان العراق القدماء، اذ بدونه لا يحصل

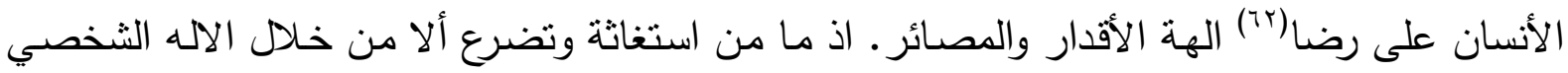
ولاسيما في الأزمات فهو الشخصية المحورية التي لولاها لما كان هناك أي قبول للتضرع(بآ، وعلى الرغم من كل هذا توصف بالكلب، ان هذا التذمر ان دل على شيءفإنما يدل على عدم اعترافه بعدل الهته. 
في ضوء ما تم دراسته يمكن ان نستتتج بعض النقاط الرئيسة للعدل الإلهي في بـاد الرافدين، ومنها ان الأنسان العراقي القديم ادرك في أوقات معينة ان الهته غير عادلة، ذلك عندما يحيط به المرض وكدر العيث.

أيضاً ان سبب أدراكه هذا يكون ناتجاً من عدم شعوره بان الإلهة ضعيفة فهي ليست بقادرة على حماية نفسها فكيف حمايته، وقد يكون أيضاً رغبته هو في تغيير الهته نتيجة لمشاهدته اليومية والتي فيها تغيير للأشياء والظواهر التي أمامه. فاراد ان يحدث التغيير حتى على الهته. ان موضوعة عدل الإلهة لم تكن مقتصرة على الإلهة الكبيرة فحسب بل امتد الأنسان العراقي القديم ليشمل بها حتى الإلهة الثخصية الحامية. ومما يمكن ان نستشفه من البحث ان موضوعة العدل الإلهي ومناقتتها لم يكن هنالك من سبق الإنسان العراقي القديم منها فهو الاول في هذا الأمر. كان لمساهمة العامل السياسي في تغيير الإلهة وبالتالي اتهام الإلهة المرشحة إلى النزول بانها غير عادلة مثلما حدث مع الاله مردوخ الذي حط من شأنه وحل محله الاله أشور . 


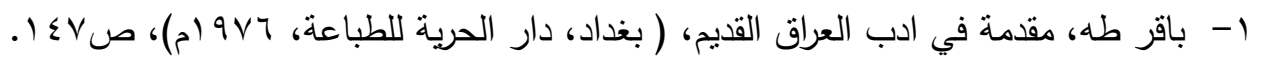

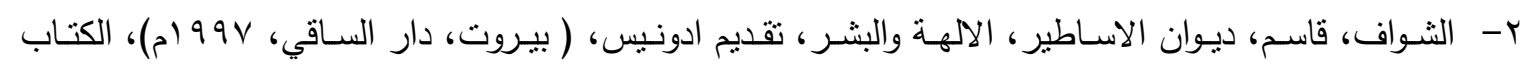

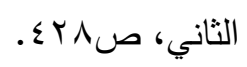

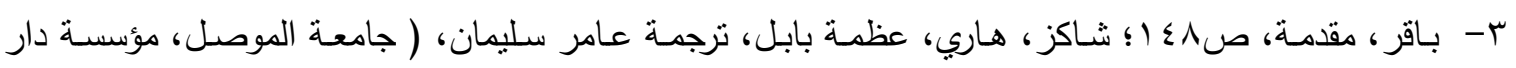

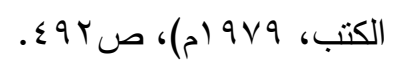

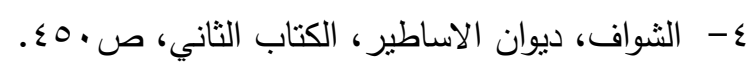

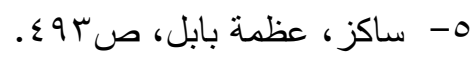

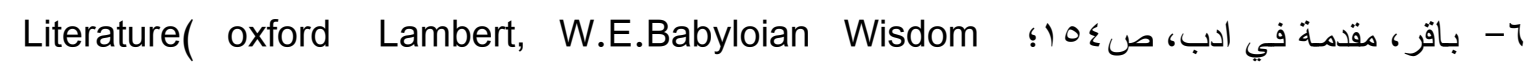

University Press, 1960), PP.64-92

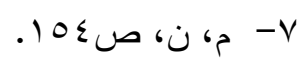

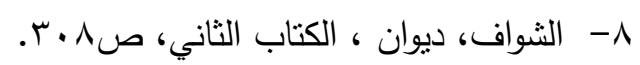

9- Chicago Assyrian Dictionary, Edited by, J Gelb and Other (Chicago, 1971), Vol.1, PP153.

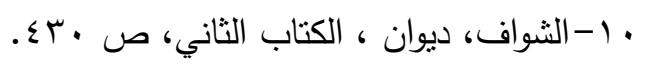

(1-علي، فاضل عبد الواحد، الطوفان في المراجع المسمارية، بغداد،( مطبعة واوفيست الاخلاص، ه و9 (م)، ص

$$
\text { ص }
$$

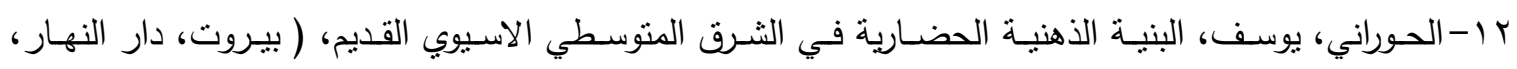

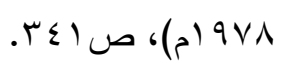

* ترجال: معنى اسمه الـ المدينة الكبيرة، وهو اله العالم الاسفل ورب المرض والمعارك الدموية. ينظر : الاحمد، سامي

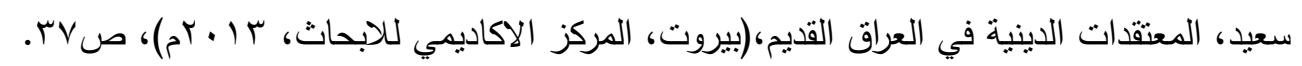

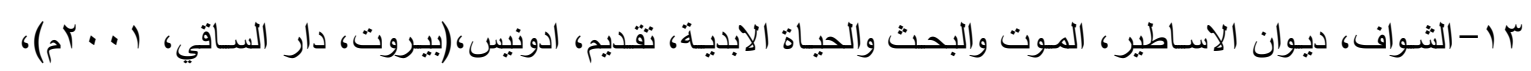

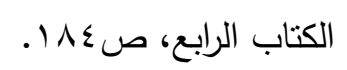

ع ا-كييرا، ادوارد، كتبوا على الطين، ترجمة محمود حسين الامين، مراجعة: علي خليل، (بغداد، مكتبة الجوادين،

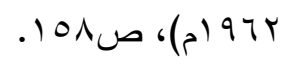

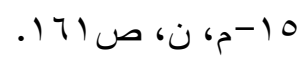


7 ا-الثواف، ديوان الاساطير ، الحضارة والسلطة، تقديم ادونيس،( بيروت، دار الساقي، 99 (م)، الكتاب الثالث،

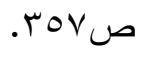

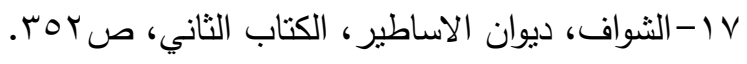

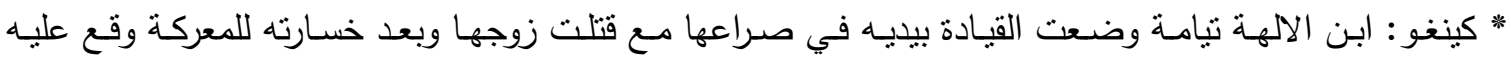
الاختيار للتضحية بـه من اجل خلق البشر • ينظر : علي فاضل عبد الواحد، عامر سليمان، عادات وتقاليد

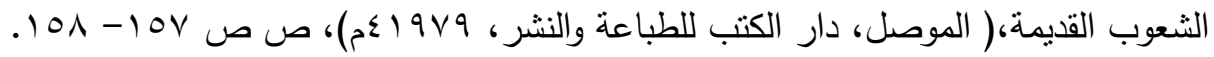

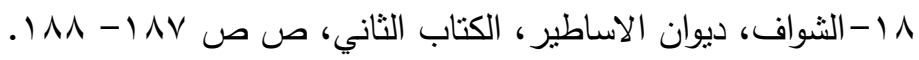

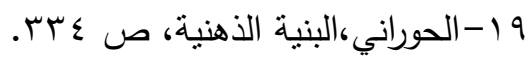

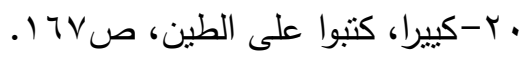

21-OInstead, A.history of Assyria, Chicago, P.414.

r ب-لابات، رينيه، المعتقدات الدينية في بلاد وادي الرافدين، ترجمة: البير ابونا ووليد الجادر ( بغداد، مطبعة التعليم

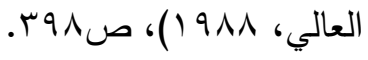

$$
\begin{aligned}
& \text { זr }
\end{aligned}
$$

ع ז-كريمر ، صموئيل نوح، السومريون، تاريخهم وحضارتهم وخصائصهم، ترجمـة: فيصل الوائلي،( الكويت، وكالة

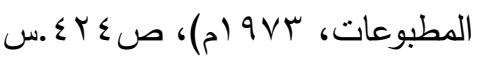

$$
\begin{aligned}
& \text { هץ-لابات، المعتقدات الدينية، ص •. ـ. } \\
& \text { דr } \\
& \text { (אע } \\
& \text { 人 } \\
& \text { و q }
\end{aligned}
$$

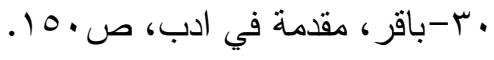

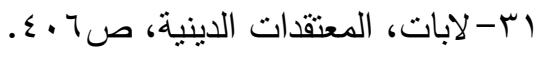

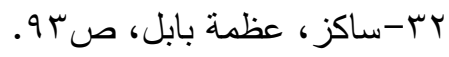

(Ansar) وهو احد ازواج الالهية الذين ولدا من (لخمو) و (لخامو) في اسطورة الخليقة البابلية. ينظر : (لنشابل Langdon.S. The Babylonian Epic Greation( Oxford, 1923), P.12. 


$$
\text { ع ـ-الاحمد، المعتقدات الدينية، صع ז. }
$$

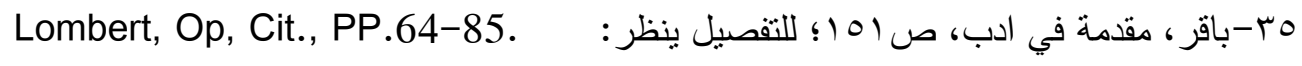

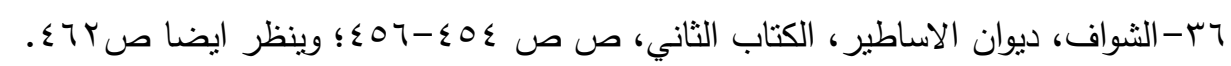

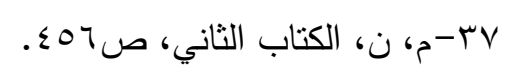

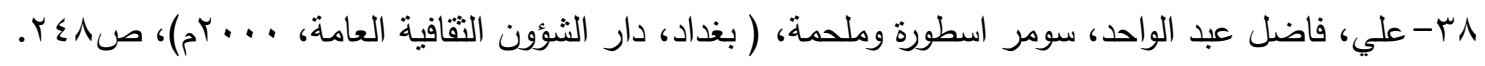

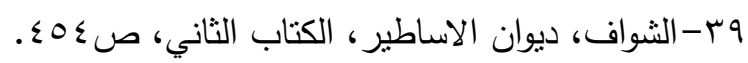

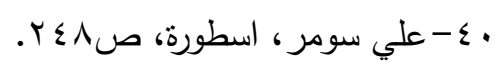

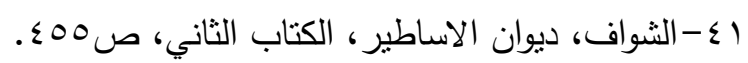

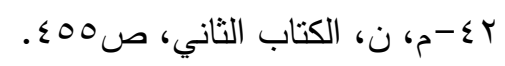

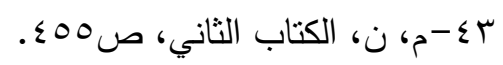

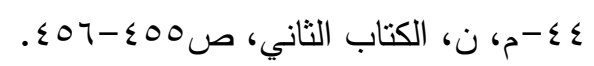

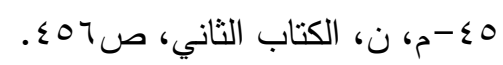
7ـ ك

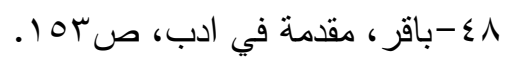

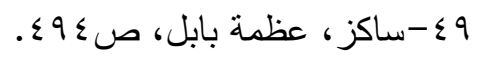

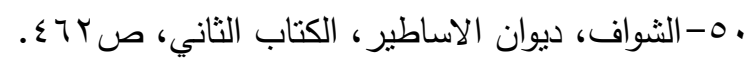

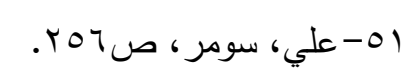

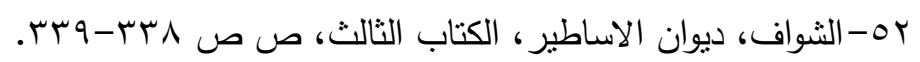

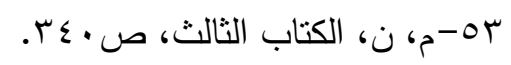

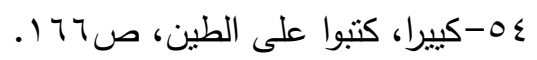

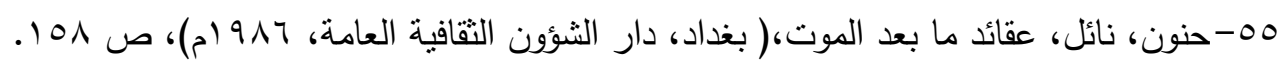

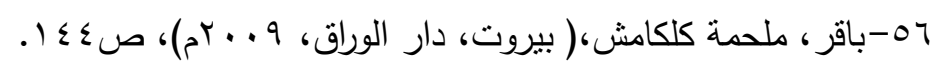

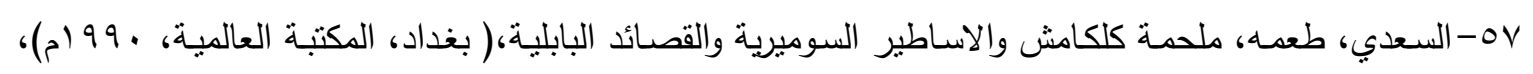
صن V.

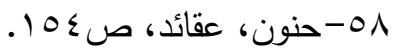

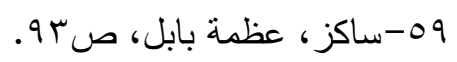




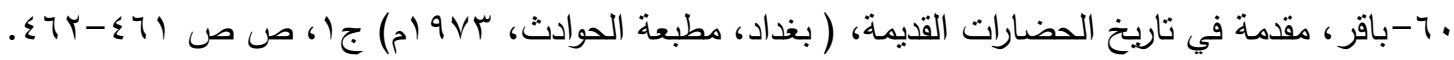

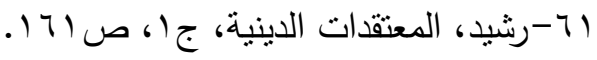

62- S.N.kramer, Sumerian Literature and B (Analecta Biblicq), Rome, 1959, P.194.

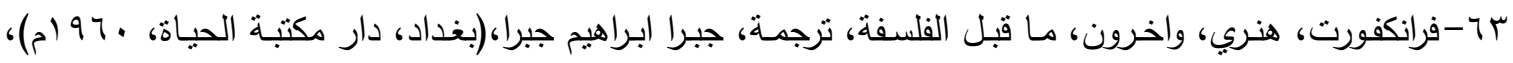
ص. 
1- الاحمد، سامي سعيد، المعتقدات في العراق القديم، ( بيروت، المركز الاكاديمي للابحاث، ب ( ب). r- باقر ، طة، مقدمة في تاريخ الحضارات القديمة،( بغداد، مطبعة الحوادث، سVو (م). ץ- ------، مقدمة في ادب العراق القديم، ( بغداد، دار الحرية للطباعة، بلو ام).

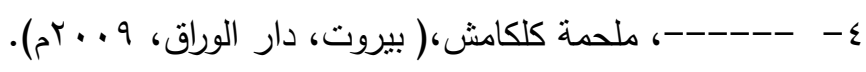
0- حنون، نائل، عقائد ما بعد الموت،( بغداد، دار الثؤون الثقافية العامة، 9191 (). צ- حوراني، يوسف، البنية الذهنية الحضارة في الشرق المتوسطي الاسيوي القديم، (بيروت، دار النهار، 9V^ (م). V- رشيد، فوزي، المعتقدات الدينية، حضارة العراق، ( بغداد، دار الحرية، 019 (م). - - ساكز ، هاري، عظمة بابل، ترجمة عامر سليمان،( جامعة الموصل، مؤسسة دار الكتب، 9 ( ام). 9- السعدي، طعمة، ملحمة كلكامش والأساطير السومرية والقصائد البابلية، (بغداد، المكتبة العالمية، . 99 (م). • 1- الثواف، قاسم، ديوان الأساطير، الالهة والبشر، تقديم: ادونيس، ( بيروت، دار الساقي، ل99 (م). (1----------، ديوان الأساطير ، الحضارة والسلطة، تقديم: ادونيس،( بيروت، دار الساقي، 999 (م).

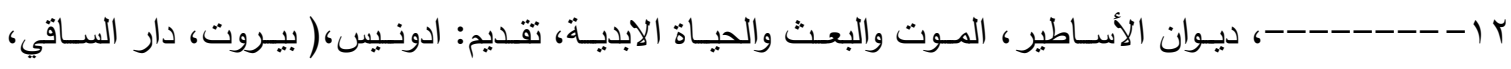
$\left.\cdot()_{r} \cdot\right)^{\prime}$

ب ا--علي، فاضل عبد الواحد، الطوفان في المراجع المسمارية، ( بغداد، مطبعة واوفست الاخلاص، هV9 (م).

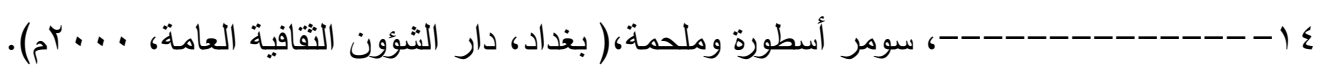
1 ا-علي ، فاضـل عبدـ الواحد، عـامر سـليمان، عـادات وتقاليد الثـعوب القديمة،(الموصـل، دار الكتب للطباعـة

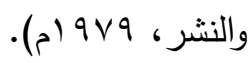

7 ا-فرانكفورت، هنري، وآخرون، ما قبل الفلسفة، ترجمة: جبرا إبراهيم جبرا،(بغداد، دار مكتبة الحياة، ـ97 (م). V V-كريمر ، صموئيل نوح، السومريون. تاريخهم وحضارتهم وخصائصهم، ترجمة: فيصل الوائلي،( الكويت، وكالة

$$
\text { المطبوعات، سV } 9 \text { (م). }
$$


1 ا-كييرا، ادوارد، كتبوا على الطين، ترجمة: محمود حسين الامين، مراجعة: علي خليل،( بغداد، مكتبة الجوادي،

$$
\text { . (م) } 974
$$

9 ا-لابات، رينيه، المعتقدات الدينية في بلاد وادي الرافدين، ترجمة البير ابونا، ووليد الجادر،( بغداد، مطبعة التعليم

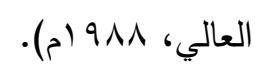

المصادر الاجنبية

1- Gelb,Jand other, Chicago Assyrian Dictionary, (Chicago, 1971).

2- Lambert, W.E.Babylonian Wisdom Literature (Oxford University Press, 1960).

3- Langdon.S.the Babylonian Epic Greation (Oxford, 1923).

4- Olmstead.A.History of Assyria Chicago. 